\title{
INTRA-REGIONAL TRADE IN SERVICES IN SOUTH AMERICA: AN INPUT-OUTPUT APPROACH
}

\author{
SANTACRUZ PEDRO BANACLOCHE SÁNCHEZ \\ Universidad de Castilla-La Mancha (UCLM), Albacete - España.
}

To cite this paper: Banacloche, S. (2017). Intra-regional trade in services in South America: an input-output approach. Revista de Administração Mackenzie, 18(6), 47-70. doi 10.1590/1678-6971 2017/administracao.v18n6p47-70

\section{ACKNOWLEDGEMENTS}

Thanks to the audience of V Redlas (The Latin American Network for Research on Services) Conference in São Paulo, as well as María Ángeles Cadarso, Nanno Mulder, and Daniel Cracau for their helpful comments and suggestions. Travel funding received from the Latin American Association of Services Exporters (ALES) is also greatly acknowledged. 


\section{ABSTRACT}

Purpose: The growing importance of the services sector is not only a fact in developed countries but is also visible in the South American subcontinent, in terms of Gross Domestic Product share, employment and foreign trade. Taking a closer look at the role of services, the present article analyzes the main linkages in trade in services in the two largest South American economies, namely, Brazil and Argentina.

Originality/Value: The recently available South American input-output table provided by United Nations Economic Commission for Latin America and the Caribbean (UN ECLAC). It is a ten-region open model that is used to study two important aspects of trade in services for the two selected economies: first, testing whether the participation of services in total trade increases when the calculation is specified in terms of value added; and second, assessing the role of services in promoting the countries' exports.

Design/methodology/approach: The present research helps to better understand the position of the region as provider and demander of intraregional services. However, the scarcity of statistics related to trade in services is a limitation that must be solved. The data was obtained from the South American input-output table. A single-regional input-output model was generated for Argentina and Brazil for 2005.

Findings: The main findings of the article include that 1 . in both economies, the participation of services in foreign trade is higher in terms of value added than under conventional gross trade data, and 2. Argentina is more integrated with the region than Brazil in terms of intra-regional imported services in its exports.

\section{KEYWORDS}

Input-output tables. Trade in services. Vertical specialization. Trade in value added. Services network. 


\section{INTRODUCTION}

Changes in the nature of international trade have occurred in the last centuries. Initially, global flows in goods were characterized by trading elaborated products for its final consumption, due to high costs in transportation and communication (Grossman \& Rossi-Hansberg, 2008). Afterwards, there was trading of intermediate goods that are inserted in the so-called Global Value Chains (GVC), through a production process consisting in allocating the different production and elaboration stages in different countries, taking advantage of different labor costs and production specialization (Elms \& Low, 2013). This is possible because of advance in transportation and communication technologies, as well as substantial reduction of associated costs. Finally, a complete product incorporates value added from different countries, making the measurement of the countries' share in the value of any goods more complex. The case of trade in services has been different from trade in goods. Services have been traditionally understood as non-tradable, because of their nature: they are intangible, perishable and production and consumption of the service activity usually happen simultaneously (take a haircut, for example). Nowadays, the increased mobility of labor and capital, together with the ongoing digitalization of the economy may turn services into tradable activities. Services such as finance, insurance or computer services cannot only be delivered within the territory of a country. Rather, common understanding defines four different modes of trade in services. Provision of the same service can be done with the provider located in a different country than the service user (cross-border supply). Services, such as travel-related activities, can be delivered to consumers of a country outside the territory of their home country (consumption abroad). The commercial presence of construction firms, or the presence of a natural person as, for example, a selfemployed lawyer or a business consultant, are other examples of trade in services (International Monetary Fund, 2009).

Thus, the role of the services sector in developed and developing economies is unquestionable. In developed countries, for example, the services sector represents at least two-thirds of the Gross Domestic Product and the employment. However, until recently, the importance of trade in services remained behind those of goods flows as its share in total goods and services trade did not exceed 20\% (Lanz \& Maurer, 2015). It was only after the Uruguay Round, in 1995, that the willingness was expressed and 
the efforts were undertaken to render commercial services information available at larger scale. Of course, this is even though its measurement has been more ambiguous and difficult than in the case of trade in goods. The growth in trade in services from $\$ 370$ billion in 1980 to $\$ 4170$ billion in 2011 highlight the need to collect data and analyze current trends (World Trade Organization [WTO], 2013). In the last decades, the commercialization of goods and services has been stimulated in such a way that the services play a role of great impact in overall trade. In the Latin American region, this takes into account especially $i$ ) the advance of new technologies and the implementation of the Internet at global scale; ii) the growth of the trade relations between Latin America and Asia; ${ }^{1}$ iii) the production process linked to global value chains; and iv) trade agreements, such as Additional Protocol of the Framework Agreement of the Pacific Alliance.

In the last decades, the globalization process has led to an increase in unprecedented trade in goods and services, accompanied by the creation of global value chains that connect productive sectors in an international context (Cadarso, Gómez-Sanz, López-Santiago, \& Tobarra-Gómez, 2008). One of the consequences of globalization has been the fragmentation of production and its offshoring. Companies adopt this strategy to compete in an international environment, where declining tariff barriers and the development of new technologies (ICTs) drive international trade (Feenstra \& Hanson, 1996). Thus, production phases can be relocated to benefit from the advantages offered by other countries, either through lower costs of labor or raw materials, etc. (Cadarso et al., 2008). This type of strategy can be realized through direct foreign investment or import from foreign suppliers located in other countries.

The present paper aims to show an initial approach to study South American intra-regional trade, focused on services in Argentina and Brazil, in order to describe the relationships of the services sectors. Two fundamental research questions will be addressed:

Q1) How does the participation of trade in services in terms of value added relate to trade measured by gross exports?

Q2) To what extent do Brazil and Argentina need to import services to realize their own exports? 
The vertical specialization as presented in Hummels, Ishii, and Yi (2001), a concept related to offshoring, is hereby applied in a way to measure the intermediate imports of services that countries require to export.

The research is organized as follows: Section 2 explains the methodology used, emphasizing the new South American Input-Output Table developed by the United Nations Economic Commission for Latin America and the Caribbean (UN ECLAC) together with Instituto de Pesquisa Econômica Aplicada (IPEA). Subsequently, Section 3 provides the main findings of the research undertaken, answering the two questions expressed above. Finally, Section 4 concludes with some key considerations.

\section{METHODOLOGY}

This section explains in detail the methodology used for the elaboration of the results set forth below. An input-output analysis has been applied elaborating a single regional model (Miller \& Blair, 2009).

\subsection{Single Regional Input-Output Model (SRIO)}

Data was obtained from the South American Input-Output Table provided by UN ECLAC. This Input-Output Table could be defined as a Ten-Region Open Model (Miller \& Blair, 2009; Nakamura \& Kondo, 2009). A Single-regional Input-Output Model (SRIO) was generated for 2005, the year, which most countries had their complete information for (ECLAC, 2016). It is a model that encompasses the linkages of the 10 South American countries included in the matrix. Its particular characteristics will be described in the next subsection.

In general, every Input-Output Table (IOT) can be divided into three main matrices: the matrix of intermediate inputs, the final demand matrix, and the value-added matrix (see Table 1). The total output or supply (total resources) is the sum by columns of intermediate inputs, imports and value added by industrial sector. The total Gross Value of Production (denoted as $x$ ) is shown in vector row $1 x N$, where, $N$ is the number of sectors IOT provides; the total demand by sector is the sum by rows of sectors, which include the intermediate inputs and the final demand offered by a column vector $N x 1$, with the accounting identity by which the row's sum is equal to the corresponding column sum. The productive structure is 
composed of sectors that produce and require intermediate inputs to produce. Thus, the matrix of intermediate inputs (denoted as $Z$ ) includes bilateral transactions in intermediate inputs, which are products used in the production of other products. Hence, $Z_{i j}$ is the domestic intermediate inputs of row sector $i$ directed towards column sector $j$. It is a square matrix, where the number of sectors is the same by rows as by columns.

\section{(Table 1) \\ SIMPLIFIED STRUCTURE OF A NATIONAL SYMMETRIC INPUT-OUTPUT TABLE (SIOT)}

\begin{tabular}{|c|c|c|c|c|c|c|c|}
\hline & & \multirow[b]{2}{*}{$\begin{array}{c}\text { Sector j } \\
123 \ldots \mathrm{N}\end{array}$} & \multicolumn{4}{|c|}{ Final demand } & \multirow[b]{2}{*}{$\begin{array}{l}\text { Total } \\
\text { Output }\end{array}$} \\
\hline & & & $\begin{array}{c}\text { Private } \\
\text { Consumption } \\
\text { (PC) }\end{array}$ & $\begin{array}{l}\text { Public } \\
\text { Expenditure } \\
\text { (GC) }\end{array}$ & $\begin{array}{l}\text { Gross Capital } \\
\text { Formation } \\
\text { (GCF) }\end{array}$ & $\begin{array}{l}\text { Exports } \\
\qquad(X)\end{array}$ & \\
\hline Sector i & $\begin{array}{c}1 \\
2 \\
3 \\
\vdots \\
\mathrm{N}\end{array}$ & $\begin{array}{l}\text { Intermediate demand: } \\
\text { Intermediate } \\
\text { consumption, } \\
\text { intermediate inputs (Z) }\end{array}$ & & Y & & & $\begin{array}{l}\text { Total } \\
\text { industry } \\
\text { Output }\end{array}$ \\
\hline \multicolumn{2}{|c|}{ Imports } & $\begin{array}{l}\text { Intermediate imported } \\
\text { inputs }\left(Z^{M}\right)\end{array}$ & & & & & \\
\hline \multirow{3}{*}{\multicolumn{2}{|c|}{$\begin{array}{l}\text { Value Added } \\
\text { (VA) }\end{array}$}} & Employee compensation & & & & & \\
\hline & & Capital compensation & & & & & \\
\hline & & $\begin{array}{l}\text { Government } \\
\text { compensation }\end{array}$ & & & & & \\
\hline \multicolumn{2}{|c|}{ Total Output } & $\begin{array}{l}\text { Total industry Output } \\
\qquad(x)\end{array}$ & & & & & \\
\hline
\end{tabular}

Source: Elaborated by the authors.

From the information provided by the matrix of intermediate inputs, the technical coefficients can be obtained; they will be used to calculate the Leontief inverse, the fundamental axis of the input-output analysis. The technical coefficients $a_{i j}$ indicate the amount of input of the sector $i$ (first subscript: row) required to produce an output unit in sector $j$ (second subscript: column):

$$
a_{i j}=\frac{Z_{i j}}{x_{j}} .
$$


In matrix form, assuming an economy composed of three sectors:

$$
A=Z \hat{x}^{-1}=\left[\begin{array}{lll}
Z_{11} & Z_{12} & Z_{13} \\
Z_{21} & Z_{22} & Z_{23} \\
Z_{31} & Z_{32} & Z_{33}
\end{array}\right]\left[\begin{array}{ccc}
\frac{1}{x_{1}} & 0 & 0 \\
0 & \frac{1}{x_{2}} & 0 \\
0 & 0 & \frac{1}{x_{3}}
\end{array}\right]=\left[\begin{array}{lll}
\frac{Z_{11}}{x_{1}} & \frac{Z_{12}}{x_{2}} & \frac{Z_{13}}{x_{3}} \\
\frac{Z_{21}}{x_{1}} & \frac{Z_{22}}{x_{2}} & \frac{Z_{23}}{x_{3}} \\
\frac{Z_{31}}{x_{1}} & \frac{Z_{32}}{x_{2}} & \frac{Z_{33}}{x_{3}}
\end{array}\right]=\left[\begin{array}{lll}
a_{11} & a_{12} & a_{13} \\
a_{21} & a_{22} & a_{23} \\
a_{31} & a_{32} & a_{33}
\end{array}\right] .
$$
in (1):

The basic equation of the Leontief open model is based on the expression

\section{in $(1)$}

$$
x=(I-A)^{-1} y,
$$

where $x$ is the total output of a given economy, which is equal to the $(I-A)^{-1}$ Leontief inverse multiplied by a final demand vector, $y$. The Leontief inverse $(I-A)^{-1}$ includes the total direct and indirect requirements throughout the country and the production chains associated with the production of a unit directed to the final demand in any sector. Finally, the I matrix is called identity matrix, a square matrix with ones in the main diagonal and zeros elsewhere, whose dimensions coincide with those of the technical coefficients. The idea behind the Leontief inverse is that each sector requires inputs from itself and other sectors. Other sectors, in turn, need inputs to produce from their own sector or other sectors, and so on.

The following expression is an illustrative example of a two-sector economy using the Leontief inverse:

$$
x=(I-A)^{-1} y=\left[\begin{array}{lll}
\beta_{11} & \beta_{12} & \beta_{13} \\
\beta_{21} & \beta_{22} & \beta_{23} \\
\beta_{31} & \beta_{32} & \beta_{33}
\end{array}\right]\left[\begin{array}{l}
y_{1} \\
y_{2} \\
y_{3}
\end{array}\right]=\left[\begin{array}{l}
x_{1} \\
x_{2} \\
x_{3}
\end{array}\right],
$$

where element $\beta_{i j}$ represents the total (this means direct and indirect) requirements that sector $i$ provides to sector $j$, so that sector $j$ can produce one unit of total output in monetary terms. If we want to analyze the Leontief inverse looking at the columns, we can obtain the total impact on production, as a consequence of an exogenous increase of one unit of final demand in column sector $j$ at hand. This column sum takes the so-called vertical integrated sectors into account since it captures the relations between sector $j$ and other sectors that provide inputs to sector $j$. A row reading focuses on the observable sectors, that is, the input transfers that a sector provides to the rest of the economy. The meaning of the Leontief inverse is that it includes 1) the unit increase in final demand, 2) inputs that are 
directly needed to produce one unit of the final product, and 3) inputs that are needed in the previous stage of production to produce inputs that are directly needed to produce one unit of the final product, and so on.

Finally, for future calculations related to value added, the Value Added per unit produced $(V)$ is presented as the gross value-added vector VA (of dimension $1 \times N$ ) divided by the gross value of production:

$$
V=V A x^{-1}=\left[\begin{array}{llll}
\frac{V A_{1}}{x_{1}} & \frac{V A_{2}}{x_{2}} & \ldots & \frac{V A_{N}}{x_{N}}
\end{array}\right]
$$

The total domestic value added (TDVA), direct and indirect, contained in a country's exports is reflected in the following formula:

$$
T D V A=\hat{V}(\mathrm{I}-\mathrm{A})^{-1} \hat{X},
$$

where $\hat{V}$ is a diagonalized $N x N$-vector of the value-added coefficients of equation (6) of a given country by industry of origin. The other components of the equation are the Leontief inverse and $\hat{X}$, the diagonalized gross exports vector. In the matrix, a row sum indicates the aggregate value of the row sector in the total requirements of an economy to be used for exports. A column sum, correspondingly, indicates the added value of the set of sectors that are incorporated in a specific sector, in order to be able to export. The most important observations at the sectoral level are the result of the sum of columns since we can compare the value added generated by the economy incorporated in the exports of sector $j$ of the economy under study. Thus, we are able to compare the share of value added in exports.

In addition, the Vertical Specialization (VS), proposed by Hummels, Ishii, and Yi (2001), using the expression in Cadarso, López, and Tobarra (2007), has been assessed. This is a relevant indicator which includes direct and indirect intermediate imports associated with a country's exports. A higher VS is related to a greater involvement among countries in the production process. It is one of the most important indicators to assess the geographical fragmentation of the international production process and the countries insertion in the global value chains. It is determined as

$$
V S=A^{M}\left(I-A^{D}\right)^{-1} \hat{X},
$$

where $A^{M}$ is the matrix of imported input coefficients, $A^{D}$ is the matrix of domestic coefficients and $\hat{X}$ is the diagonalized gross exports vector. The column sum of the resulting matrix indicates the intermediate imports of any product that is directly or indirectly necessary to obtain the exports 
corresponding to a sector. In this case, if we divide the sum of the elements of the column by the exports of the sector, we obtain the vertical specialization of this sector per unit of gross exports (Cadarso et al., 2008).

Due to the relative simplicity of the Input-Output Model, the Leontief open model is generated under some assumptions, which can also be seen as providing the main limitations of the analysis (Schuschny, 2005):

A. In the symmetrical input-output tables, each input is supplied by a single production sector, through the Product Technology Assumption or the Industry Technology Assumption. This means that the secondary productions of all sectors are relocated to the sectors whose main production they belong to (sectoral homogeneity hypothesis). As a consequence, each sector produces only a single (representative) product with a homogenous input structure;

B. The amount of intermediate inputs necessary for production varies proportionally to the desired production. This implies that the composition of the production (or the representative product) of each sector is fixed (strict proportionality hypothesis). Furthermore, the production functions are linear, the technical coefficients are constant and there are constant returns to scale. Technical coefficients assume that every firm in one sector has the same production technology and the same efficiency levels;

C. Changes in prices are not considered and are therefore not related to changes in the use of physical inputs. Input-Output Tables valued in monetary terms assume all flows in the economy to be equivalent to (or represented by) the physical flows of goods and services. A differentiated price system in the economy is not considered (an assumption often considered as being a really strong one). Furthermore, there is no substitutability between inputs; and

D. The model does not consider the incorporation of all durable goods in the production process within the matrix. Capital goods as, for example, constructions, machinery or vehicles, are included in the formation of the gross capital as a part of the final demand, which is exogenous, rather than including capital goods as a primary factor capable of providing productivity.

However, the input-output model has advantages that make it a useful methodology for the analysis of global value chains and any quantifiable 
multiplier. It is a model that collects all complex relations between different industries of different countries in the form of a matrix, showing inter and intra-industrial relations, key sectors of the economy of the countries, as well as main commercial relations.

\subsection{Database: The South American Input-Output Table}

For the analysis of the present work, data has been obtained from the South American Input-Output Table (SA IOT), a publicly available database that provides information on the production processes in the region. ${ }^{2}$ This matrix includes 10 South American countries: Argentina, Bolivia, Brazil, Chile, Colombia, Ecuador, Paraguay, Peru, Uruguay, and Venezuela. Its year of reference is 2005 . It has a structure of 40 sectors with transactions valued at basic prices and intermediate consumption (intermediate use) differentiated in domestic and imported. Moreover, it includes vectors of imports and exports by country/region. A total of seven sectors, out of the 40 sectors comprising the IOT, are services, namely: Electricity and gas; Construction; Transportation; Telecommunications; Finance and insurance services; Business services of all kinds; and Other services, whose main component is given by sectors related to tourism. One of the main advantages of using this IOT is that it provides additional information by country/sector of origin in the case of intermediate inputs, and country of destination in the case of the final demand. Thereby, linkages can be identified within the region. For better understanding, Table 1 illustrates a simplified version of SA IOT, representing the structure of a standard IOT.

Other international IOT databases like the World Input-Output Database (WIOD) or Trade in Value Added (TiVA) do not include many countries from South America. If they do, the sectoral structure often does not fit the region requirements. Therefore, another advantage of the SA IOT is its sectoral structure, which has been adapted and designed to capture the primary and extractive-led sectors that define the region productive structure.

SA IOT has been jointly created by the Economic UN ECLAC and the Brazilian Institute for Applied Economic Research (IPEA) with the purpose to provide a useful tool for the analysis of production linkages and integration in a region, where IOTs have not been previously assembled in this way.

Accessible online at: www.cepal.org/es/publicaciones/40271-la-matriz-insumo-producto-america-surprincipales-supuestos-consideraciones 
Thanks to the information available in this database, both at production and trade levels, SA IOT provides a suitable database for the development of this work.

It is worth mentioning the limitations on trade in services, given the inherent difficulty of accounting for trade in services. The current version of SA IOT provides a general reading of the services share in the regional trade, although only three countries present information of bilateral trade in services statistics by origin and destination: Brazil, Chile and Colombia. For the other countries, the following estimates have been applied: pattern of bilateral flows of goods that are complementary to service activities (as for Communications); pattern of bilateral flows of Foreign Direct Investment (for Finance and insurance services); mirror data; and satellite accounts like the Tourism accounts from the System of National Accounts. For a better understanding of SA IOT, methodological and practical manuals are available (ECLAC, 2016; Durán \& Banacloche, 2017).

\section{(Table 2) \\ SOUTH AMERICAN INPUT-OUTPUT TABLE}

(Simplified structure)

\begin{tabular}{|c|c|c|c|c|c|}
\hline & & \multicolumn{3}{|l|}{$\begin{array}{l}\text { South American } \\
\text { Countries }\end{array}$} \\
\hline & & & $\begin{array}{l}\text { Sectors j } \\
123 \ldots 40\end{array}$ & $\begin{array}{c}\text { Final } \\
\text { Demand }\end{array}$ & Total production \\
\hline $\begin{array}{c}\text { South } \\
\text { American } \\
\text { Countries }\end{array}$ & Sectors i & $\begin{array}{r}1 \\
2 \\
3 \\
\vdots \\
40\end{array}$ & $\begin{array}{l}\text { Intermediate } \\
\text { inputs (Z) }\end{array}$ & $y$ & $x$ \\
\hline $\begin{array}{l}\text { Rest of the } \\
\text { world }\end{array}$ & \multicolumn{2}{|c|}{ Imports } & $\begin{array}{l}\text { Intermediate imported } \\
\text { inputs }\left(Z^{M}\right)\end{array}$ & & \\
\hline & \multirow{2}{*}{\multicolumn{2}{|c|}{$\begin{array}{l}\text { Value added } \\
\qquad \text { (VA) }\end{array}$}} & $\begin{array}{c}\text { Employee } \\
\text { compensation }\end{array}$ & & \\
\hline & & & Capital compensation & & \\
\hline & \multicolumn{2}{|c|}{ Total production } & $x$ & & \\
\hline
\end{tabular}


To finish with the explanation of the SA IOT characteristics, it is necessary to mention that this IIOT is incomplete. More specifically, it is a Regional Open Model where certain information is not available. This includes the intermediate inputs exported from South America to the rest of the world, the relations between extra-regional countries in the trade of intermediate goods and services, and the final demand satisfied from extraregional countries. Thus, SA IOT can be understood as an extended Single Regional Input-Output (SRIO) with the advantage of providing additional information about the country-origin of the intermediate imported inputs originated within South America. This type of tables can be found at every regional level: a city, a state, a country or a group of countries. Although these IOT are not as common as the national IOT or IIOT, some examples can be found in those provided by the Asian Development Bank [ADB] (2015) or the Institute of Developing Economies [IDE], Japan External Organization [JETRO] (2005).

An exhaustive study of GVC using the South American Input-Output Table is not possible, due to the limitations explained above. Future efforts to close this ten-region Open Model will help deepen the analysis of productive linkages and the fragmentation phenomenon not only among the countries from the region but also with respect to the rest of the world. However, SA IOT is suitable to study trade in the region, since its assembly has considered a specific sectoral choice, which responds to the productive characteristics of the region (ECLAC, 2016). In addition, the rest of the databases on IIOT generally do not include most Latin American countries, or their assembly includes particular assumptions and estimates.

\section{RESULTS}

This section describes the relationships between the services sectors of the two major South American countries, in order to determine the regional supply chains as well as to measure indicators such as vertical specialization associated with trade in the region.

As a first approximation of the importance of services, the great increase in trade in services at global scale stands out. We observe an annual growth rate of $9.9 \%$ between 2000 and 2010 , driven mainly by telecommunications, information and information services (with a $16.7 \%$ annual growth), finance and insurance services ( $13.3 \%$ and $11.2 \%$, respectively), and other business 
services $(11.7 \%)$, which encompasses a wide range of services: research and development services; professional consulting and management; trade-related technical services; agricultural, mining; operational leasing; etc. Thanks to the proliferation of the Internet and the digitalization of the economy, which broadens the possibilities for global interconnection, service exports have increased faster than goods in the last decade, also showing greater resilience. In 2014, services registered a $20.2 \%$ share in the total exported goods and services (ECLAC, 2015).

Looking at South America, some differences between countries appear both in terms of Gross Domestic Product (GDP) and the share of services in total trade (see Chart 1). In 2005, when considering the seven service sectors embodied in SA IOT, services in Argentina and Brazil contributed $48 \%$ and $73 \%$, respectively, to the total GDP. This contribution falls to $34 \%$ in the case of Argentina and $64 \%$ in the case of Brazil, when Electricity, gas, and construction sectors are not included.

\section{(Chart 1)}

\section{SOUTH AMERICA: SERVICES CONTRIBUTION TO GROSS DOMESTIC PRODUCT AND SHARE IN TOTAL TRADE, 2005}

(In percentage)

\begin{tabular}{lcc} 
& Gross Domestic Product & Trade in goods and services \\
\hline Argentina & $48 \%$ & $9 \%$ \\
\hline Bolivia & $57 \%$ & $2 \%$ \\
\hline Brazil & $73 \%$ & $15 \%$ \\
\hline Chile & $65 \%$ & $16 \%$ \\
\hline Colombia & $69 \%$ & $6 \%$ \\
\hline Ecuador & $65 \%$ & $2 \%$ \\
\hline Paraguay & $43 \%$ & $7 \%$ \\
\hline Peru & $57 \%$ & $6 \%$ \\
\hline Uruguay & $75 \%$ & $28 \%$ \\
\hline Venezuela & $47 \%$ & $0 \%$ \\
\hline South America & $67 \%$ & $11 \%$ \\
\hline
\end{tabular}

Source: Elaborated by the authors based on the South American Input-Output Table (ECLAC, 2016). 
In terms of services exports, Argentina's trade in services accounted for $9 \%$ of total exports in goods and services; $6 \%$ when electricity, gas and construction sectors are excluded. Brazilian services share is about $15.4 \%$ of the total exports in goods and services. The share does not show big changes when excluding Electricity, gas, and construction sectors. In terms of GDP, services in countries like Uruguay, Chile, and Colombia have a high share. In terms of international trade, Uruguay and Chile are the most serviceintensive exporting countries. On the opposite, services in countries, such as Venezuela, Bolivia or Ecuador, do not have a relevant position.

The main services sectors in the South American region represented in SA IOT are Other services, and Business services of all kinds, both in terms of GDP participation and share in trade in services (see Graph 1). Sectors such as Transportation are also important, because of the geographic extent of the main economies like Brazil and Argentina. In terms of international trade, Transportation is always related to trade in goods, since this service enables the circulation of goods. Therefore, $25 \%$ of trade in services comes from Transportation. On the other side, some limitations appear in trade in services such as electricity and gas, and construction, due to the nature of these services. In the case of electricity and gas, infrastructure is needed to be a tradable service. In the case of construction, the firms are suppliers through commercial presence in the territory of the service importer. That means trade occurs when the service is provided within the destination country by a locally-established affiliate, subsidiary, or representative office of a foreign-owned and controlled company. This specific example is captured by the Mode 3 of trade in services as established in the General Agreement on Trade in Services (International Monetary Fund [IMF], 2009). One of the main differences between the region and the rest of the world appears in the pattern of trade in services. When looking at trade in services at a global scale, transportation and travel accounts in the Payment Balance have become less relevant during the last decades, while other services (for example business services, computer and telecommunication services) have increased their share. In the case of South America, business services and other services related to finance and insurance are highly relevant in 2005. That can be seen in Graph 1, where the other services sector (determined by travel-related activities) and transportation account for around $50 \%$ of the total services exports in South America. 


\title{
(Graph 1)
}

\section{SOUTH AMERICA: MAIN SERVICES SECTORS IN GROSS DOMESTIC PRODUCT AND INTERNATIONAL TRADE, 2005}

\author{
(In percentage)
}

Gross Domestic Product

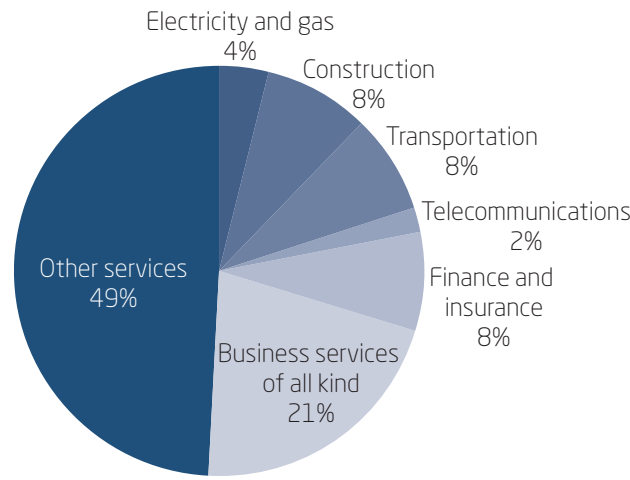

Trade in services

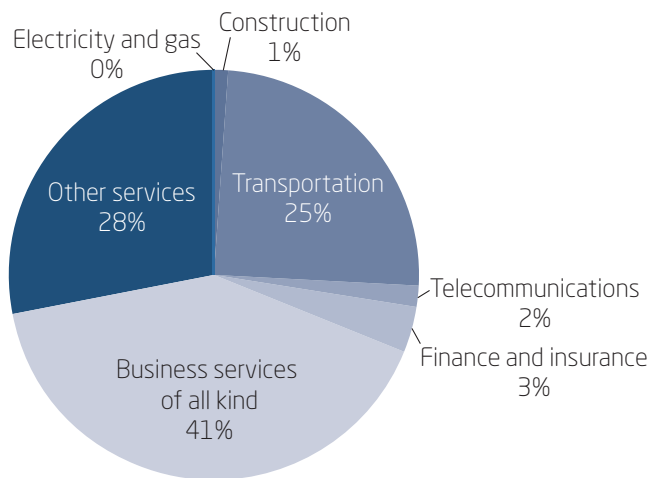

Source: Elaborated by the authors based on the South American Input-Output Table (ECLAC, 2016).

Research Question Q1: How does the share of trade in services in terms of value added relate to trade measured by gross exports?

When measuring gross exports, Brazil stands out as the main services exporter (55\%) among all South American countries in SA IOT, followed by Chile (20\%) and Argentina (11\%). Countries like Colombia, Peru or Uruguay are the next countries in services exports to the world (in gross terms). Paraguay and Venezuela are ranked at the bottom of the services exports.

Chart 2 summarizes the export pattern of the two South American countries at hand. As mentioned above, Brazil is the main service provider in the region. In absolute terms, Brazil provides services that account for $\$ 19,287$ million. Argentina holds the third place with services exports that account for $\$ 2,756$ million ( $\$ 3,801$ million when accounting also Electricity and Construction sectors). Note that while Brazil reveals a clear trend to direct its services exports to destination outside the region with a mere $1.2 \%$ intra-regional service exports, Argentina is more integrated regionally with $38.7 \%$ of its services directed to South America.

In both Argentina and Brazil, the share of trade in services in total trade considering value added terms is higher than the share calculated with the gross export data. This holds for both intra-regional and extra-regional trade (see Fig. 4). These results include the domestic value added that a country needs to satisfy foreign final demand, considering not only direct but also 
indirect requirements needed in the production process. In the case of Argentina, the share of services measured in terms of value added is higher in intra-regional trade than in extra-regional trade. Thus, Argentina's exported services are more important within its intra-regional trade relations. In Brazil, in contrast, the pattern is reversed with a higher share of services measured in terms of valued added in its extra-regional trade compared to its intraregional trade.

\section{(Chart 2)}

ARGENTINA AND BRAZIL: EXPORT PATTERN, 2005

(In million dollars)

\begin{tabular}{lcccccc} 
& \multicolumn{3}{c}{ Goods } & \multicolumn{4}{c}{ Services } \\
\cline { 2 - 7 } & Intra-regional & Extra-regional & Total & Intra-regional & Extra-regional & Total \\
\hline Argentina & 15,369 & 24,682 & 40,051 & 1,067 & 1,689 & 2,756 \\
\hline Brazil & 19,325 & 89,580 & 108,905 & 228 & 19,059 & 19,287 \\
\hline
\end{tabular}

Note: Electricity and Construction sectors have not been included.

Source: Elaborated by the authors based on the South American Input-Output Table.

\section{(Graph 2)}

ARGENTINA AND BRAZIL: SHARE IN FOREIGN TRADE, 2005

(In percentage)

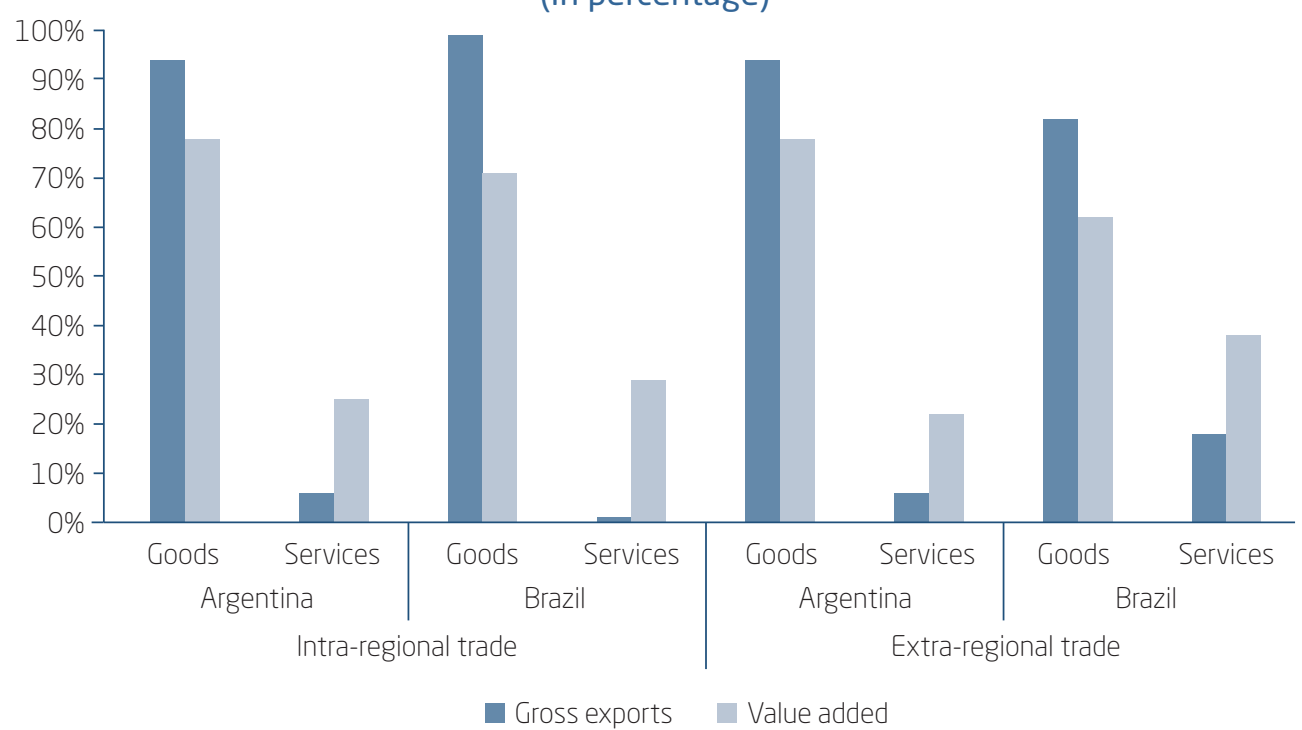

Note: Electricity and Construction sectors have not been included. 
A sectoral analysis as illustrated in Graph 3 shows the relevance of the so-called Other services sector, which includes sectors, such as government services, computing and computer science, royalties and licenses, personal and cultural services, and travel. The travel sector accounts, on average, for around $80 \%$ of the other services sector in South American countries (ECLAC, 2016). A clear example of the importance of the travel account is given in Argentina and Brazil, whose touristic attractions render them a reference at a regional level. They rank as the most visited countries in South America, in number of international arrivals, followed by Chile and Peru (United Nation World Tourism Organization [UNWTO], 2016). Transportation is also an important services sector, particularly because of the geographic extension of these countries and their maritime access. It is further necessary to emphasize the importance of the business services of all kinds, that include services such as real estate activities, rental of machinery and equipment, computer services and related activities, development, and other business activities. ${ }^{3}$ These services have been defined as the glue that supports the value chains (Hernández, Hualde, Mulder, \& Sauvé, 2016). Looking at the extra-regional trade only, Brazil stands out with a high share of business services of all kinds, while Argentina seems rather specialized in other services. However, the general trade pattern between intra-regional and extraregional trade in services is similar.

Looking at the bilateral intra-regional trade, the main commercial relations are between Brazil, Argentina, and Chile. Thus, to conclude, it is worth highlighting the possible existence of nearshoring within the region (Fig. 6). The balance of intra-regional trade in services is negative in almost all countries except for Brazil, Chile, and Argentina. Such a deficit does not necessarily imply weakness, it may just suggest an increase in the use of external services as means to increase the competitiveness of the other sectors of the economy of a country, mainly for export (ECLAC, 2007). It may only become worrying in the case of Bolivia and Venezuela, whose dependence on South American services is remarkable.

Computer services and related activities are especially important services in Uruguay, Brazil, Chile and Argentina (ECLAC, 2007). 


\section{(Graph 3) \\ ARGENTINA AND BRAZIL: TRADE IN SERVICES \\ SHARE BY SECTORS, 2005}

(In percentage)

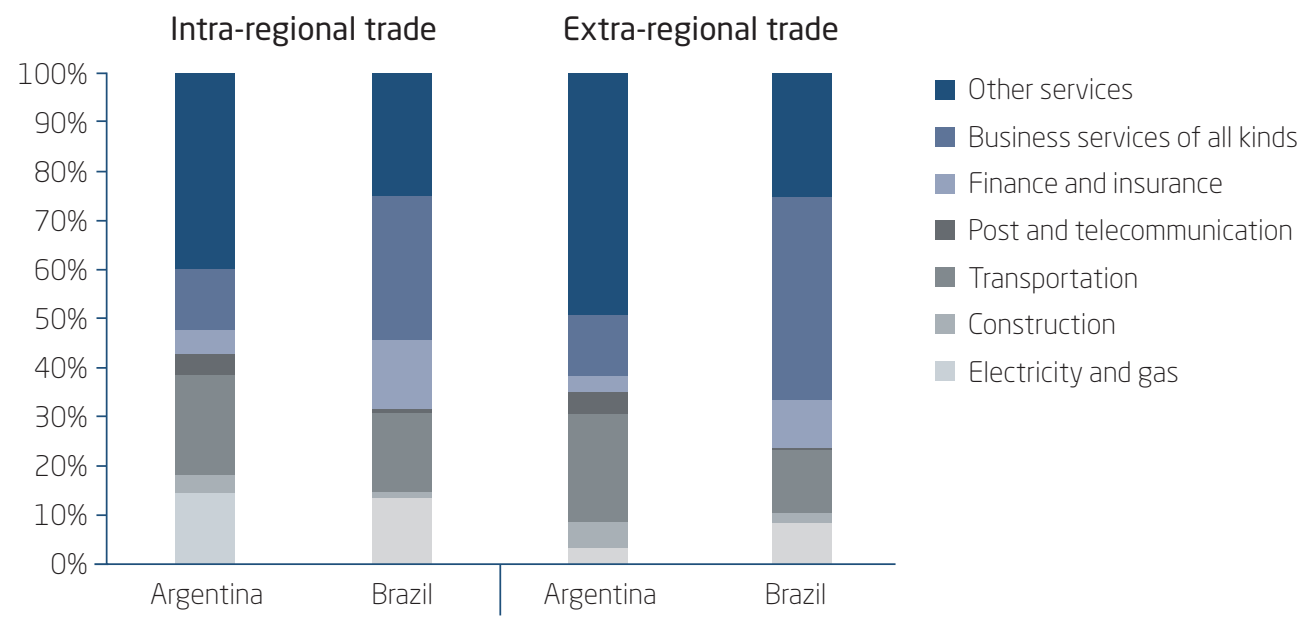

Source: Elaborated by the authors based on the South American Input-Output Table.

\section{(Graph 4)}

\section{ARGENTINA AND BRAZIL: INTRA-REGIONAL TRADE IN SERVICES BY PARTNER COUNTRIES, 2005}

(In percentage)
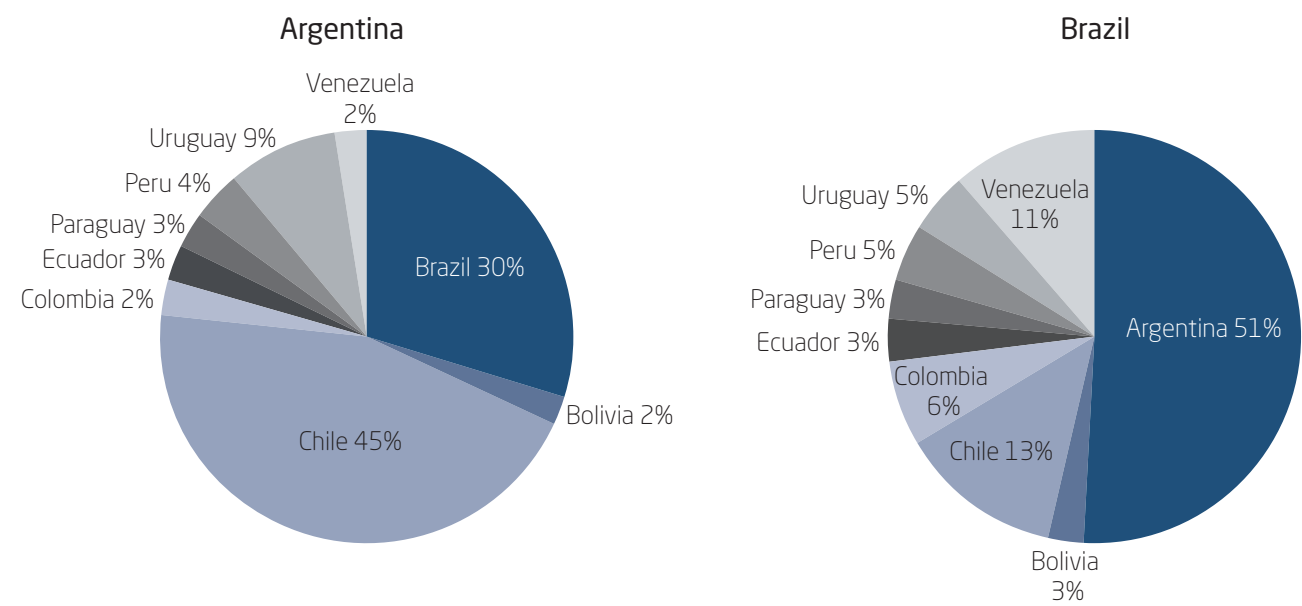

Source: Elaborated by the authors based on the South American Input-Output Table. 
Research Question Q2: To what extent do Argentina and Brazil need to import services to realize their own exports?

The trend of international trade observed at global level is reflected by the globalization phenomenon and the geographical fragmentation of production. Efforts to boost international trade through reduction of tariff barriers, trade facilitation, and other instruments have led to relocation of production, where companies move phases of their production processes beyond their borders. Reorganization of the production process, such as outsourcing, offshoring, nearshoring and GVCs, prove the importance of this process (Grossman \& Rossi-Hansberg, 2008; Shamis, Green, Sorensen, \& Kyle, 2005). In this direction, vertical specialization is an indicator that captures information on the fragmentation of production, relating it to exports (Cadarso et al., 2008).

Vertical specialization is defined by Hummels, Ishii, and Yi (2001) as the use of external intermediate inputs in the production of final products that are then exported. It should be noted that by using this definition, the production phases of given product can be determined, since it can be identified which countries become part of a single production chain (Backer \& Yamano, 2012). Following that concept, at least three countries are involved in such a productive sequence: the finished product of country $B$ incorporates imported content from country $A$ and is ultimately exported to a third country $C$, where the product is needed to satisfy the domestic demand of the economy. Thus, on the one hand, an evaluation of Vertical Specialization (VS) provides results related to the offshoring phenomenon, since a higher VS value means that the country is more involved in the fragmentation of the production process of goods and services. On the other hand, the VS may show the potential deficiencies in the domestic production of some intermediate goods and to what extent a country depends on imported intermediates to facilitate its own exports. Technically, the share of total imported requirements needed to export is derived by reading VS by columns and dividing the sum of the column elements by the exports of the sector. It is necessary look at the VS with a focus on services.

Chart 3 shows the calculation of the VS indicator for Argentina and Brazil by country of origin. For Argentina, the imported content is $11.6 \%$ of the gross exports. A significant proportion of this imported content of approximately $\$ 4,950$ million comes from the South American region (40.7\%), more specifically from Brazil ( $\$ 1,556$ million). Looking at Brazil, imported content is $13.5 \%$ of the gross exports. Confirming the pattern already observed above, this imported content is mainly from extra-regional origins, leaving intra-regional share of VS at (16.5\%) only. Brazilian imports can be mainly explained by inputs from Argentina and Chile. 


\section{(chart 3)}

\section{VERTICAL SPECIALIZATION IN SERVICES: SERVICES IMPORTED IN ARGENTINA AND BRAZIL, 2005}

(in million \$)

\begin{tabular}{lrrlrc}
\hline \multicolumn{1}{c}{ Argentina } & \multicolumn{1}{c}{ VS } & VS in services & \multicolumn{1}{c}{ Brazil } & \multicolumn{1}{c}{ VS } & VS in services \\
\hline Brazil & $1,555.95$ & 5.34 & Argentina & $1,246.10$ & 13.27 \\
\hline Bolivia & 65.03 & 0.00 & Bolivia & 243.57 & 0.08 \\
\hline Chile & 121.53 & 0.01 & Chile & 830.39 & 16.75 \\
\hline Colombia & 12.08 & 0.00 & Colombia & 27.35 & 1.97 \\
\hline Ecuador & 0.89 & 0.00 & Ecuador & 25.94 & 3.71 \\
\hline Paraguay & 176.02 & 55.30 & Paraguay & 87.69 & 0.00 \\
\hline Peru & 13.82 & 0.00 & Peru & 210.76 & 0.00 \\
\hline Uruguay & 58.65 & 2.77 & Uruguay & 109.96 & 34.33 \\
\hline Venezuela & 9.03 & 0.00 & Venezuela & 74.82 & 3.88 \\
\hline Intra-regional & $2,013.00$ & 63.42 & Intra-regional & $2,856.59$ & 74.00 \\
\hline Extra-regional & $2,936.72$ & 0.44 & Extra-regional & $14,421.10$ & $2,020.70$ \\
\hline
\end{tabular}

Source: Elaborated by the authors based on the South American Input-Output Table.

The explanations provided above consider the imported content of goods and services in exports. If we assess the imported services needed in Argentina and Brazil to realize their exports, the main finding suggests that Brazil does not depend on intra-regional services on a large scale to export. Only $0.06 \%$ of the exports relate to intra-regionally imported services. This compares to $1.58 \%$ of extra-regional imported services facilitating the Brazilian exports. On the contrary, Argentina strongly depends on intraregionally imported services to export. Still, the imported content of exports is only about $0.15 \%$ (compare Chart 3 ).

Finally, Graph 5 illustrates the origin of the imported content of services in Argentinian and Brazilian exports. In this case, Electricity and Construction sectors were included, because of the role of Paraguay as a net exporter of electricity. ${ }^{4}$ Argentinian service imports contained in its exports exclusively stem from its MERCOSUR neighbors Brazil, Paraguay, and Uruguay. Brazil

This is explained by the Itaipu Dam, the hydropower plant that is one of the largest producers of power in the world and that is jointly owned by Paraguay and Brazil. 
additionally imports services contained in its exports from Chile (23\%), as well as Colombia, Ecuador, and Venezuela, although at a smaller scale.

\section{(Graph 5)}

ARGENTINA AND BRAZIL: SERVICES VS IN GROSS EXPORTS, 2005

(In percentage)
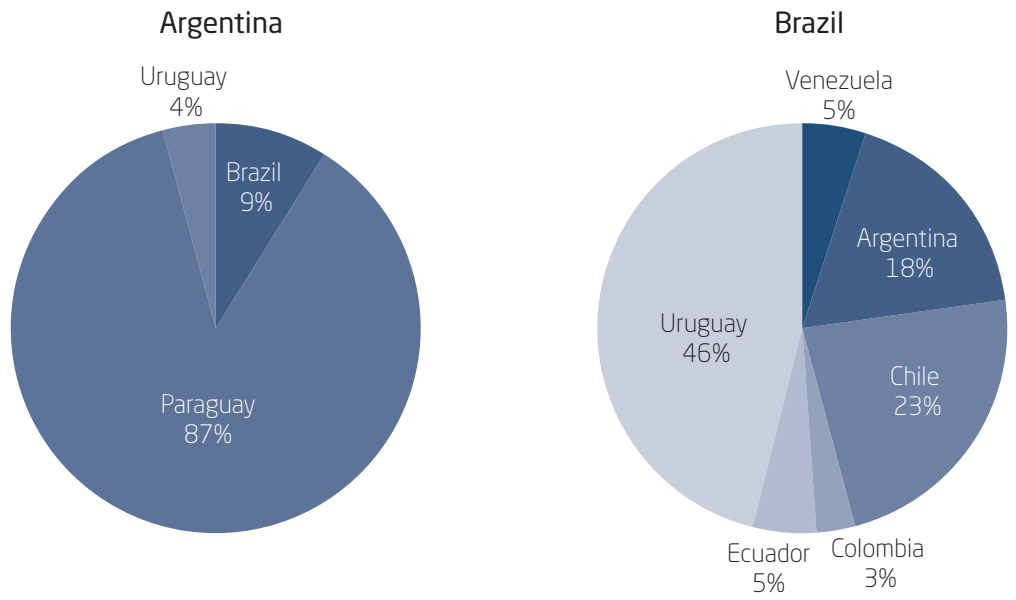

Source: Elaborated by the authors based on SAIOT. Note: Electricity and Construction have been included.

\section{CONCLUSIONS}

When measuring trade in services in terms of value added, its contribution to the foreign trade in goods and services substantially increases in Argentina and Brazil compared to the gross exports terms, both when assessing intraregional and extra-regional trade. The main differences between Argentina and Brazil appear when focusing on the origin and the destination of traded services. Argentina's services exports are to intra-regional a large extent. Furthermore, most imported services contained in the Argentinian total exports come from the region. One example is the electricity required from Paraguay, which Argentina needs to export. In Brazil, trade in services is more extra-regionally oriented. This becomes visible when looking both at the services exports in value added terms and the imported services contained in the Brazilian exports by country of origin.

Business services are significantly important for the Brazilian trade in value added terms, as they have become a key factor in the economic development, since these activities foster the outsourcing that has accompanied the 
flexibilization of production. They also facilitate the incorporation of SMEs in international trade activities by using ICTs, and enable integration between the producing industries and the services sectors. The importance of ICTs to make services tradable, entering the global value chains and generating linkages in the region is vital.

The present research has been developed with the South American Input-Output Table that helps to understand the region's position as provider and demander of intra-regional services better. Computer services, business services, telecommunications and transport services are essential for an industry to relocate and hence, currently, these are activities closely related to the phenomenon of fragmented production.

It is important to highlight the main limitation of the research, which is the scarcity of statistics related to trade in services. This lack of information leads to an ambiguous quantification of some indicators related to trade in services. For example, Argentina didn't report statistics on bilateral trade in services by country of origin and some assumptions had to be undertaken in this regard. Thus, obtaining information on trade in services is a challenge, and a concern, for the whole South American region. It is necessary to apply tools and methodologies that promote the measurement of trade in services and facilitate the information, so that future analysis on the services sector are more solid and can be undertaken at a greater level of detail.

Finally, further analysis of regional value chains and employment by gender, as well as qualification, would be interesting to determine the degree of inequality in the region. This would enable formulation and implementation of economic and social policies that could not only address existing inequalities but also could promote a greater economic integration for the region. Also, analysis that extends the methodology presented in this article to the remaining countries included in the South American Input-Output Table or that measures the manufacturing servicification (Lanz \& Maurer, 2015) would contribute to consolidate the understanding of the trade in services pattern in the region.

\section{$\int$ REFERENCES}

Asian Development Bank. (2015). Key Indicators for Asia and the Pacific 2015. Retrieved from https://www.adb.org/publications/key-indicators-asiaand-pacific-2015 
Backer, K. de, \& Yamano, N. (2012). International comparative evidence on global value chains. OECD Science, Technology and Industry Working Papers, (2012/03). doi 10.1787/18151965

Cadarso, M. A., Gómez-Sanz, N., López-Santiago, L. A., \& Tobarra-Gómez, A. (2008). Especialización Vertical en la Industria y los servicios: convergencia en la Unión Europea. Revista de Estudios Empresariales, (1), 65-87.

Cadarso, M. A., López, L. A., \& Tobarra, M. A. (2007). Vertical Specialization, Outsourcing and Direct Investment in the Spanish Manufacturing Sector. Revista de Economía Mundial, 16, 27-55.

Economic Commission for Latin America and the Caribbean (ECLAC), \& Institute of Applied Economic Research (Ipea). (2016). The South American input-output table - Key assumptions and methodological considerations. Santiago: United Nations. Retrieved from http://www20.iadb.org/intal/catalogo/ PE/2011/07891.pdf

ECLAC. (2015). Latin America and the Caribbean in the World Economy 2015 The regional trade crisis: assessment and outlook. Santiago: United Nations. Retrieved from http://repositorio.cepal.org/bitstream/handle/11362/ 39011/4/S1501141_en.pdf

ECLAC. (2007). Trade in services in Latin America and the Caribbean: An analysis of recent trends. Santiago: United Nations. Retrieved from http://repositorio. cepal.org/bitstream/handle/11362/4429/1/S0700970_en.pdf

Elms, D. K., \& Low, P. (Eds.). (2013). Global value chains in a changing world. Geneva: World Trade Organization. Retrieved from https://www.wto.org/ english/res_e/booksp_e/aid4tradeglobalvalue13_e.pdf

Feenstra, R. C., \& Hanson, G. H. (1996). Globalization, Outsourcing, and Wage Inequality. American Economic Review, 86 (2), 240-245. Retrieved from http://www.jstor.org/stable/2118130

Grossman, R. M., \& Rossi-Hansberg, E. (2008). Trading tasks: A simple theory of offshoring. American Economic Review, 98(5), 1978-1997. doi 10.1257/ aer.98.5.1978

Hernández, R., Hualde, A., Mulder, N., \& Sauvé, P. (Eds.). (2016). Innovation and internationalization of Latin American services. Santiago: United Nations. Retrieved from https://www.cepal.org/en/publications/40301-innovationand-internationalization-latin-american-services

Hummels, D., Ishii, J., \& Yi, K. (2001). The nature and growth of vertical specialization in world trade. Journal of International Economics, 54 (1), 75-96. doi 10.1016/S0022-1996(00)00093-3 
Institute of Developing Economies (IDE) \& Japan External Trade Organization (JETRO). (2005). Asian international input-output table 2005(Technical notes). Japan: IDE-JETRO. Retrieved from http://www.ide.go.jp/English/Data/Io International Monetary Fund (IMF). (2009). Balance of Payments and International Investment Position Manual (6th ed.). Washington, D.C.: FUD.

Lanz, R., \& Maurer, A. (2015). Services and global value chains: Some evidence on servicification of manufacturing and services networks. Geneve: World Trade Organization. Retrieved from https://www.econstor.eu/bitstream/ 10419/107675/1/819620912.pdf

Lima, J. E. D., \& Álvarez, M. (2013). Indicadores de comercio exterior y política comercial: análisis y derivaciones de la balanza de pagos. Santiago: Economic Commission for Latin America and the Caribbean (ECLAC).

Miller, R. E., \& Blair, P. D. (2009). Input-output analysis: Foundations and extensions. Cambridge: Cambridge University Press.

Shamis, G. S., Green, M. C., Sorensen, S. M., \& Kyle, D. L. (2005). Outsourcing, offshoring, nearshoring: What to do? Journal of Accountancy, 199(6), 57-61. Retrieved from https://search.proquest.com/docview/206 779058 ? accountid $=41816$

Schuschny, A. R. (2005). Tópicos sobre el modelo de insumo-producto: Teoría y aplicaciones. Santiago: United Nations.

Nakamura, S., \& Kondo, Y. (2009). Waste input-output analysis: Concepts and application to industrial ecology. Tiergartenstrasse: Springer.

United Nation World Tourism Organization (UNWTO). (2016). UNWTO Tourism Highlights 2016 Edition. Madrid: UNWTO. Retrieved from www. e-unwto.org/doi/pdf/10.18111/9789284418145

World Trade Organization. (2013). World Trade Report 2013. World Trade Organization, Geneva, Switzerland: WTO Secretariat.

\title{
ABOUT THE AUTHORS
}

\author{
SANTACRUZ PEDRO BANACLOCHE SÁNCHEZ \\ Master degree in Economic Growth and Sustainable Development \\ from the Faculty of Economic and Business Sciences, \\ Universidad de Castilla-La Mancha (Spain). \\ $\mathrm{PhD}$ student from the Faculty of Economic and Business Sciences, \\ Universidad de Castilla-La Mancha (Spain). \\ Consultant at the Division of International Trade and Integration, \\ Economic Commision for Latin America and the Caribbean. \\ Cirujano Guzmán 70, Providencia - Santiago - Región Metropolitana - Chile \\ E-mail: santacruz.banacloche@alu.uclm.es
}

